\title{
Bleached kenaf microfiber as a support matrix for cyclodextrin glucanotransferase immobilization via covalent binding by different coupling agents
}

\begin{abstract}
Enzyme immobilization via covalent binding provides a strong interaction between enzyme and support material. In this study, the effect of different coupling agents (spacer arms and ligands) in cyclodextrin glucanotransferase (CGTase) immobilization on bleached kenaf microfiber as a support matrix was investigated. The immobilized CGTase properties such as storage stability, thermal stability and reusability were evaluated. Immobilized CGTases on microfiber resulted in $0.162-0.24 \mathrm{U} / \mathrm{mg}$-fiber when $55.6 \mathrm{U} / \mathrm{mL}$ of CGTase activity was initially added during the immobilization. The highest storage stability $\left(60{ }^{\circ} \mathrm{C}\right)$ was shown by CGTase that was immobilized with ethylenediamine and o-phthalaldehyde, whereby $60 \%$ of its activity remained after 15 days. Its high stability was also confirmed by the lowest deactivation constant, $\mathrm{kd}$ that was obtained at $25{ }^{\circ} \mathrm{C}\left(0.0161\right.$ day-1) and $60{ }^{\circ} \mathrm{C}(0.0361$ day-1). The CGTase immobilized using ethylenediamine and glutaraldehyde has shown the best retention of enzyme activity up to $72.72 \%$ after 12 cycles of batch reaction. The results indicate that kenaf microfiber has potential to be applied as a support for enzyme immobilization and its enzymatic properties were affected by the coupling agents.
\end{abstract}

Keyword: Cyclodextrin glucanotransferase (CGTase); Bleached kenaf microfiber; Covalent immobilization; Spacer arm; Ligand 